\title{
Performance of brassica cultivars from New Zealand and United States seed sources in Southeast Ohio, USA
}

\author{
CHRISTOPHER D. PENROSE', HENRY M. BARTHOLOMEW', R. MARK SULC ${ }^{2}$ \\ STEVEN D. SCHUMACHER', RICK DUFF ${ }^{3}$ \\ ${ }^{1}$ OSU Extension, Athens Co. $280 \mathrm{~W}$. Union St. Athens, OH 45701 USA \\ 2 The Ohio State University, Columbus, Ohio, USA \\ ${ }^{3} 15826$ Bucks Lake Rd. Guysville, Ohio 45735, USA
}

\begin{abstract}
A bstract
Four turnip cultivars, two swede, and one each of kale, rutabaga and Chinese-cabbage turnip hybrid were evaluated for their usefulness in extending the grazing season. The three replicates were planted on 28 July 1994 and harvested on 31 October and 3 November 1994. Dry matter yields ranged from $5460 \mathrm{~kg} / \mathrm{ha}$ for Premier kale to 8877 $\mathrm{kg} / \mathrm{ha}$ for Rondo turnip. Rondo turnip total yield of $\mathrm{DM}$ was significantly higher $(\mathrm{P}=0.05)$ than all other cultivars except Doon Major swede. Crude protein levels ranged from $8.5 \%$ to $24.3 \%$ for the tops and $5.9 \%$ to $13.4 \%$ for the bulbs, with NDF fibre levels of $17.6 \%$ to $21.4 \%$ for tops and $15.6 \%$ to $20.4 \%$ for the bulbs. All cultivars survived temperatures of $-10^{\circ} \mathrm{C}$ with Premier kale being the most winter hardy, surviving the winter minimum temperature of $-21^{\circ} \mathrm{C}$. Forage brassicas can provide high levels of quality forage for the late autumn and early winter period, significantly extending the grazing season in Ohio and the midwest US.
\end{abstract}

Keywords: brassica, Chinese cabbage-turnip hybrid, grazing season, kale, rutabaga, swede, turnip

\section{Introduction}

Extending the grazing season to reduce costs is critical for Ohio cattle and sheep producers' economic viability in an increasingly competitive world market. Normally, $50-60 \%$ of forage growth from traditionally grazed temperate grasses and legumes in Ohio occurs within a 2-month period in the spring (Bartholomew et al. 1994). Growth of, temperate forage species typically slumps during the often hot and dry continental summers in the midwest US and recovers slightly during the autumn months. Producers have traditionally relied on stored feed as the primary source of nutrition for livestock up to 5 months of the year. Feed costs account for over $90 \%$ of the variable costs on many cow-calf operations and the major portion of that cost is for hay production. A 1987 Ohio study indicated that stored feed costs for 25 cow-calf producers averaged NZ\$322 (Fowler \&
Stout 1990). Brassicas are a viable option to extend the grazing season in the late autumn and early winter, and hence reduce winter feeding costs.

Interest is growing in managed grazing systems and extending the grazing season in Ohio. Many livestock producers are looking to the success of New Zealand producers and are interested in forage cultivars that have been developed or used in New Zealand. Many New Zealand varieties of grasses and legumes are being grown successfully in the midwest US. The brassica family is often overlooked by US producers as a feed source. A comparison of brassica from US and New Zealand seed sources was conducted to assess each cultivar's suitability to our region. New Zealand's climate is generally more moderate than the Midwest. The latitude at the trial site was $38^{\circ} \mathrm{N}$, comparable to the northern regions of New Zealand's North Island.

Forage brassica crops such as turnip, swede, rape and kale can be spring-seeded to supplement perennial forages in late summer, or more commonly, summerseeded to extend the grazing season into early winter. Brassicas are annual crops which are highly productive and digestible and grazing can be commenced 70-150 days after seeding, depending on the species (Hall \& Jung 1992).

Generally brassicas which produce bulbs will outyield those which do not. Considerations in determining which cultivar will be best suited for a particular use will be: grazing method, and whether the bulbs can be efficiently utilised by the species of livestock. Sheep are more efficient at grazing bulbs than cattle. Cattle can make good use of both the tops and bulbs when strip grazed. This grazing method greatly reduces the waste from trampling.

\section{M aterials and methods}

A replicated trial was conducted in Southeast Ohio in 1994. Forage brassicas were seeded into a sod composed of temperate perennial species with a no-till drill on 28 July. Nine days prior (19 July) a burn-down herbicide of 0.56 litres of glyphosate was used for sod suppression. The swede, rutabaga, and turnips were seeded at a rate of $2.1 \mathrm{~kg} / \mathrm{ha}$, while kale was seeded at $4.2 \mathrm{~kg} / \mathrm{ha}$. Seeding 
rates are usually $0.9-1.8 \mathrm{~kg} / \mathrm{ha}$ for turnips and 4.5-5.4 $\mathrm{kg} / \mathrm{ha}$ for kale.

The soil was an Omulga silt loam with an 8-15 degree slope. The $\mathrm{pH}$ was $7.0 ; \mathrm{P}_{2} \mathrm{O}_{5}$ level was $9 \mathrm{~kg} / \mathrm{ha}$ (Bray $\mathrm{P}_{1}$ ); $\mathrm{K}_{2} \mathrm{O}, 214 \mathrm{~kg} / \mathrm{ha}$; Ca, $2391 \mathrm{~kg} / \mathrm{ha} ; \mathrm{Mg}, 414$ $\mathrm{kg} / \mathrm{ha}$. Plots were fertilised at planting with $50 \mathrm{~kg} / \mathrm{ha} \mathrm{N}$, $23 \mathrm{~kg} / \mathrm{ha} \mathrm{P}_{2} \mathrm{O}_{5}$, and $23 \mathrm{~kg} / \mathrm{ha} \mathrm{K}_{2} \mathrm{O}$.

Nine varieties of brassica were used in the trial, including three from Challenge seeds, New Zealand (now Wrightson Seeds). The plots were randomised in a complete block design with three replications. The plots were harvested on 31 October (replicate 1) and 3 November (replicates 2 and 3). All replications were harvested for dry matter (DM) yield by sampling three $61 \mathrm{~cm}^{2}$ subplots per replication, while replications one and three were analysed for crude protein (CP), neutral detergent fibre (NDF) and mineral concentration.

Two types of statistical analysis were used to analyse the results. Analysis of varience with LSD was used to test significant differences of cultivars. Also, separation of means was accomplished by Fisher's protected LSD.

\section{Results}

Total DM yields ranged from $5460 \mathrm{~kg} / \mathrm{ha}$ for Premier kale to $8877 \mathrm{~kg} / \mathrm{ha}$ for Rondo turnip. Tyfon Chinese cabbage-turnip hybrid, and Appin stubble turnip had the highest yields of tops, while Rondo had the highest yield of bulbs. Rondo and Doon Major had the highest combined yields of tops and bulbs. Rondo turnip tops were significantly higher $(\mathrm{P}=0.05)$ in $\mathrm{CP}$ than the kale, rutabaga, Tyfon, and Wintergreen (Table 1). The $\mathrm{K}$ and $\mathrm{Ca}$ levels in the tops were high and similar to those reported in other trials. Calcium levels in the bulbs averaged approximately $25 \%$ of the tops. There was no significant difference among brassicas for $\mathrm{CP}$ in the bulbs. Although there was no significant difference in NDF among species, the fibre levels were extremely low. The phosphorus in the tops (not shown in Table 1) ranged from $0.18-0.22 \%$ while the bulbs ranged from $0.18-0.24 \%$. There were no significant differences in $\mathrm{P}$ levels among the cultivars tested $(\mathrm{P}=0.05)$.

\section{Discussion}

Yields were higher in the 1994 study than in previous studies (Bartholomew \& Underwood 1991) conducted during 1989 and 1990 in similar trials in adjoining counties (within $60 \mathrm{~km}$ ). In 1989, Rondo turnip DM yields were $2677 \mathrm{~kg} / \mathrm{ha} ; 1990,4283 \mathrm{~kg} / \mathrm{ha}$ : and 1994 , $8877 \mathrm{~kg} / \mathrm{ha}$. Another cultivar used in all three trials was Purple Top turnip which yielded $2676 \mathrm{~kg} / \mathrm{ha}$ in 1989; $4461 \mathrm{~kg} / \mathrm{ha}$ in 1990; and $5936 \mathrm{~kg} / \mathrm{ha}$ in 1994 .

Although the 1994 yields were higher than in previous area studies, the yields are consistent with previous studies conducted in Pennsylvania (Jung 1983). The previous Ohio studies were sown in tilled soil while the 1994 trial was no-tilled.

Although adequate moisture is required for maximum growth, particularly at germination, brassicas are quite tolerant of dry conditions once established. A trial conducted in 1993 was abandoned owing to an extreme drought during which no rainfall was received for the 40 days after seeding. Saturated soil conditions are not well tolerated by brassicas. Brassicas are tolerant of cool temperatures but should not be planted too late in the growing season if high yields are desired. Weather conditions during the trial were ideal for the germination and development of the brassicas. The day after seeding, $29 \mathrm{~mm}$ of rain fell and during the growing season of

Table 11994 brassica study, Athens Co. Ohio, USA-components of yield.

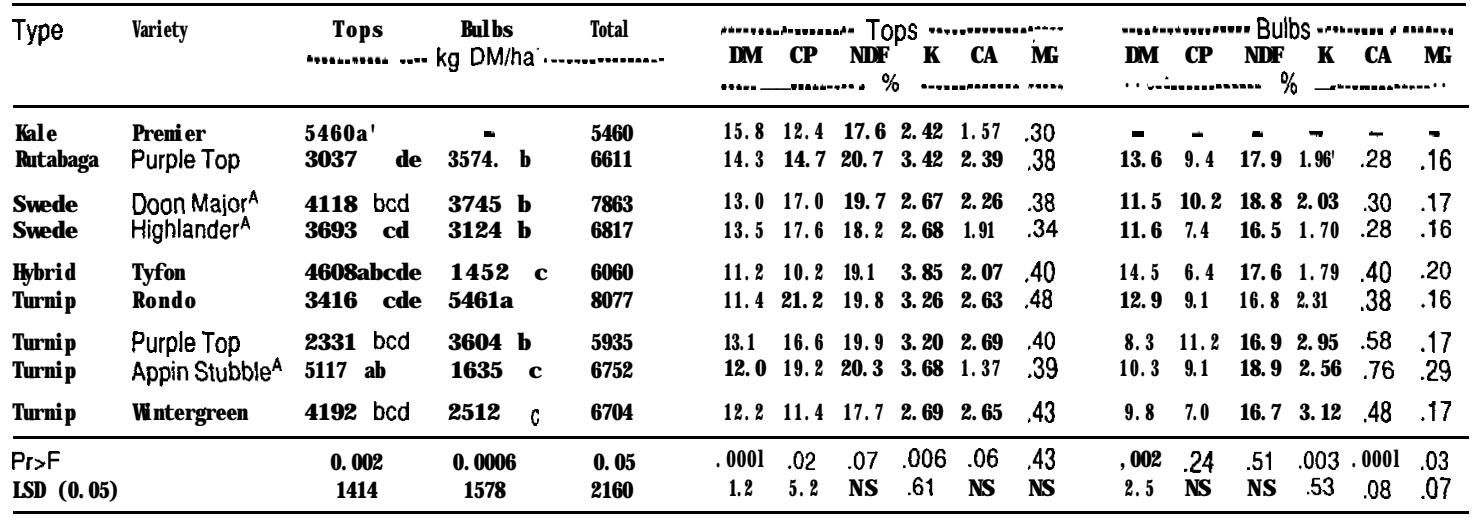

- Neans with the sane letter are not significantly different.

A From New Zealand Seed Sources. 
the crop, $214 \mathrm{~mm}$ of rain fell. The temperatures were much above normal for late summer-early autumn providing more heat units than average. This indicated planting earlier in the summer is necessary to achieve these yields routinely for late season grazing.

Top growth on turnips will generally survive temperatures of between -6 and $-10^{\circ} \mathrm{C}$, while bulbs will tolerate temperatures about $3^{\circ} \mathrm{C}$ lower than this (Bartholomew \& Underwood 1991). In the 1994 trials, Premier kale survived the entire winter, with a winter minimum temperature of $-22^{\circ} \mathrm{C}$. All of the cultivars survived temperatures of $-11^{\circ} \mathrm{C}$ on 30 November. During late autumn-early winter (December), quality declined. On 13 January 1995, after temperatures of $-22^{\circ} \mathrm{C}$, all of the cultivars except Premier kale displayed damage. Highlander swede still had $33 \%$ of its tops green and the bulbs were still intact. Wintergreen turnip had a similar proportion of tops intact, but the bulbs were starting to soften. Appin stubble turnip had approximately $25 \%$ of the tops green and the bulbs were very firm. Doon Major swede and American Purple Top turnip still had firm bulbs, but the majority of the tops were brown. By April, 1995, Premier kale had recovered from the winter and resumed rapid growth.

Brassicas are high in protein as a percentage of $\mathrm{DM}$, as well as being very low in fibre and high in digestibility, making them a high quality feed for many kinds of livestock. The combination of high protein and high levels of some mineral with low fibre can cause scouring in some livestock species. The incorporation of some lower quality roughage can slow the rate of passage and improve animal performance (Bartholomew \& Underwood 1991). Calves grazing Rondo turnips at the Southern Branch of Ohio Research and Development Center from 14 November 1994 to 6 January 1995 gained an average of $0.6 \mathrm{~kg} /$ day for a total of $314 \mathrm{~kg}$ liveweight gain/ha. The 25 calves consumed $1800 \mathrm{~kg}$ of poor quality grass hay during this period. Nitrogen fertiliser should be limited to $45-50 \mathrm{~kg} / \mathrm{ha}$ to minimise potential nitrate toxicity. Sheep do an excellent job of grazing both tops and bulbs with little trampling loss, while cattle may waste up to $50 \%$ of the bulbs produced. Strip grazing is highly recommended for cattlc for cultivars which have a high percentage of their yield in the tops.

\section{Conclusion}

Trials in Southeast Ohio have demonstrated the potential of brassica to extend the grazing season. The use of brassicas is increasing as more producers see benefits. As acceptance has grown, interest is increasing in locating other members of the brassica family for testing in Ohio. In this evaluation, Doon Major swede, Highlander swede and Appin Stubble turnip all were acceptable in DM, yield, and CP content. Highlander swede is very winter hardy in our area and could be saved for grazing in December and January. In this trial, all cultivars were well accepted by lambs and stocker calves.

Brassicas can provide good yields of high quality forage to extend the grazing season and reduce winter feeding costs. They are especially useful for young growing stock with high nutritional requirements. Special precautions should be taken owing to possible high nitrate levels, mineral imbalances and low fibre content. Brassicas should be grazed in combination with other stockpiled grasses or grass hay to reduce potential metabolic and digestive disorders and to balance mineral content, particulary for cattle.

\section{REFERENCES}

Bartholomew, H.M.; Cline, J.H.; Hendershot, R.E.; Bottles, S.L.; Ware AS. 1994. Extending Forage Availability to Develop Year-Round Grazing. Ohio Rural Rehabilitation Program, Ohio Department of Agriculture.

Fowler, K.F.; Stour, T.T. 1990. Cow-calf profitability in southeast Ohio: Twenty-Five 1987 Cases. Ohio Beef Cattle Research and Industry Report. Animal Science Series 90-Z: 86-90. The Ohio State University.

Hall, M.H.; Jung, J.A. 1992. Use of brassica crops to extend the grazing season. Agronomy Fact Sheet \# 33. Penn State University.

Jung, G.A. 1983. Conservation Tillage for Forage Brassicas. Journal of soil and water conservation. Vol. 43, Number 3: 230.

Bartholomew, H.M.; Underwood, J.F. 1991. Brassicas for Forage. Agronomy Factsheet (AGF-020). Ohio State University Extension. 